\title{
Expression of Heat-labile Enterotoxin of Escherichia coli in Biolistic Transformed Hairy Roots of Daucus carota L.
}

\author{
Sharada Laxman Deore*, Someshekhar S. Khadabadi, Bhushan A. Baviskar
}

Sharada Laxman Deore*, Someshekhar S. Khadabadi, Bhushan A. Baviskar

Govt. College of Pharmacy, Kathora naka, Amravati-444604, MS, INDIA.

\section{Correspondence}

Sharada Laxman Deore

Govt. College of Pharmacy, Kathora naka, Amravati-444604, MS, INDIA

Email: sharudeore_2@yahoo.com

History

- Submission Date: 11-01-2019;

- Review completed: 01-08-2020;

- Accepted Date: 15-08-2020

DOI : 10.5530/pj.2020.12.198

Article Available online http://www.phcogj.com/v12/i6

\section{Copyright}

(C) 2020 Phcogj.Com. This is an openaccess article distributed under the terms of the Creative Commons Attribution 4.0 International license.

\section{ABSTRACT}

Expression and secretion of recombination proteins in transgenic hairy roots have opened door to simple, feasible and economic option compared to animal and bacterial systems. Here, we report a feasibility study for producing the nontoxic B subunit of Escherichia coli heatlabile enterotoxin (LTB) in Daucus carota $L$ hairy root where transformation is achieved by biolistic gene gun method. Agrobacterium rhizogenes strain (R-1000) cells containing synthetic LTB gene in PMYO51T plant expression vector under the CaMV 35S promoter introduced to Daucus carota $L$ roots by biolistic gene gun method. PCR amplification confirmed the integration of synthetic LTB gene in carrot hairy roots. Western blot analysis confirmed production of LTB pentamer in similar banding pattern to the native bacterial derived LTB. $0.50-0.70 \%$ of LTB protein estimated in carrot hairy roots. GM1-ganglioside assay indicated formation of biological active pentamers. LTB protein with biochemical properties identical to native LTB protein in the hairy roots of edible carrot roots opens the way for inexpensive, safe, and effective plant-based edible vaccines for humans and animals.

Key words: Carrot, hairy root, Gene gun, LTB.

\section{INTRODUCTION}

Production of antigens and antibodies in plant provide a potential approach for the development of vaccines for oral delivery. ${ }^{1}$ Traditional vaccines are facing challenges like storage, distribution and administration but recently their safety and effectiveness has also raise many issues. ${ }^{2}$ Expression and secretion of recombination proteins, antigens and antibodies through transgenic hairy roots in confined media under controlled environment have opened door to simple, feasible and economic option compared to animal and bacterial systems. ${ }^{3,4}$ Hairy roots are non-photosynthetic and rapidly grow in simple culture media without requirement of phytohormones. Easy genetic manipulation, low-cost downstream purification and easy scaleup in bioreactors attract researchers to hairy roots. ${ }^{5}$

Heat-labile enterotoxin (LT) protein composed of one A-subunit (LTA, $27 \mathrm{kDa}$ ) and five noncovalently associated B-subunits (LTB, 11.6 $\mathrm{kDa}$ each) forming a ring-like pentamer from Escherichia coli causes diarrhea. ${ }^{6}$ Wild-type LT is toxic and therefore unsuitable for clinical use. Non-toxic LTB has high affinity towards the toxin receptor ganglioside GM1, a glycosphingolipid found ubiquitously on the surface of mammalian cells. Previous research confirmed that recombinant LTB could potential mucosal and parenteral vaccine adjuvants to stimulate strong serum and mucosal immune responses against LT.

Nontoxic B subunit of Escherichia coli heat-labile enterotoxin (LTB) has been expressed in a number of plant species with favourable quantity, including potato (17 lg g-1 FW), tomato (38 lg g-1 DW), tobacco $(75 \mathrm{lg}$ g-1 FW) and carrot (3 lg LTB g-1
FW). ${ }^{7}$ However, present study reports biolistic gene gun mediated expression of LTB proteins in Daucus carota L hairy roots first time.

\section{MATERIALS AND METHODS}

\section{Transformation vector}

pMYO51T containing synthetic LTB gene (414 bp) controlled by the CaMV $35 \mathrm{~S}$ promoter is used as plant expression vector. ${ }^{7}$ The recombinant plasmid was diluted 10 times, and $10 \mu \mathrm{L}$ of this sample was used to transform $100 \mu \mathrm{L}$ of Agrobacterium rhizogenes strain (R-1000) (at OD600 $\mathrm{nm}=1$ ) using the freeze-thaw method. A. rhizogenes strain (R-1000 ATCC) cells containing pMYO51T + synthetic LTB gene were added to YEB solid culture medium and activated three times at $27^{\circ} \mathrm{C} .^{8}$ A single colony isolated from the Petri dish was then inoculated into $25 \mathrm{~mL}$ YEB liquid culture medium and grown overnight at $27^{\circ} \mathrm{C}$ shaking incubator. This suspension culture is used for further experiments.

\section{Plant material}

One month laboratory grown carrot (Daucus carota L) roots were thoroughly cleaned with running tap water and disinfected by rinsing in $75 \%$ ethanol $(v / v)$. The cleaned explants were finally treated with $\mathrm{HgCl} 2$ (0.1\%) for 6-8 min under aseptic conditions and washed 5 times with sterile distilled water to remove traces of $\mathrm{HgCl} 2$. Then, the surface sterile carrot root was sliced into several $0.5 \mathrm{~cm}$ thick discs and the cortex from approximately half of the pieces was further trimmed to expose the cambium and pre-cultured $^{8}$ for 2 days on Murashige and Skoog (MS) medium added with $0.5 \mathrm{mg} / \mathrm{L}$ auxin before Agrobacterium transformation.

Cite this article: Deore SL, Khadabadi SS, Baviskar BA. Expression of Heat-labile Enterotoxin of Escherichia coli in Biolistic Transformed Hairy Roots of Daucus carota L. Pharmacogn J. 2020;12(6):1440-3. 


\section{DNA bullet preparation}

The gold particle stock was prepared by dissolving $60 \mathrm{mg}$ of gold particles of size $1 \mu$ provided by BioEra Life Sciences in $1 \mathrm{ml}$ of 50 $\%$ sterile glycerol and vortexed for 5 min to avoid agglomeration of particles. The coating of plasmid DNA $(0.5 \mu \mathrm{g})$ onto gold particles was carried according to manufacturers protocol (Bio-Era). This included vortexing plasmid DNA and gold particles for 2-3 min in a solution of $20 \mu \mathrm{l}$ of $0.1 \mathrm{M}$ spermidine and $50 \mu \mathrm{l}$ of $2.5 \mathrm{M} \mathrm{CaCl} 2$ followed by centrifugation at $5000 \mathrm{rpm}$ for $5 \mathrm{~min}$, collected pellet was rinsed twice subsequently in $150 \mu \mathrm{l}$ of 70 and $100 \%$ ethanol. The coated microparticles were then re-suspended in $50 \mu \mathrm{l}$ of $100 \%$ ethanol and kept on ice until bombardment. For each bombardment $10 \mu$ of these microcarriers was used. ${ }^{9}$

\section{Establishment of hairy roots}

Pre-cultured carrot explants were bombarded with gold particles (1 $\mu \mathrm{m})$ at $50 \mu \mathrm{g} / \mu \mathrm{L}$ concentrations coated with $2.0 \mu \mathrm{g} / \mu \mathrm{L}$ of pMYO51T + synthetic LTB added A. rhizogenes culture using a Biolistic gene gun system (BioEra -Particle bombardment System) at 800 psi pressure and $6 \mathrm{~cm}$ flight distance. Further these materials were co-cultured on liquid MS medium at $25^{\circ} \mathrm{C}$ in the dark. ${ }^{8}$ After three days, the explants were transferred to fresh MS medium supplemented with $300 \mathrm{mg} / \mathrm{L}$ of cefotaxime and $100 \mathrm{mg} / \mathrm{L}$ of kanamycin and were maintained at $25^{\circ} \mathrm{C}$ under a $16 / 8 \mathrm{~h}$ light/dark photoperiod for two weeks. The developed hairy roots were subsequently transferred at two-week intervals to fresh MS agar containing antibiotics and incubated at $25^{\circ} \mathrm{C}$ in the dark. Healthy hairy roots were further analysed by PCR to confirm genomic DNA integration.

\section{PCR analysis}

Genomic DNA was extracted from the 2- week old hairy roots of carrot and screened by PCR to confirm presence of LTB sequence $^{10}$ using specific primers for the LTB gene: Forward: 5'-GGATCCGCCACCATGGTGAAGGTGAAG-3' and Reverse: 5'-GGTACCTCATAGCTCAT-CTTTC-3'. PCR products were subjected to electrophoresis on $0.8 \%$ agarose gel and stained with ethidium bromide.

\section{Growth of hairy roots}

The hairy roots confirmed to be transgenic were transferred to a $250-\mathrm{ml}$ Erlenmeyer flask containing liquid MS medium without antibiotics and were grown at $28^{\circ} \mathrm{C}$ in the dark with mild shaking, refreshed medium weekly for two months for further experiments.

\section{Extraction and purification of total proteins}

The total proteins $\mathrm{s}^{7,8,10}$ of $5 \mathrm{~g}$ transgenic hairy root were extracted using phosphate buffer (100 mM, pH 7). First, the hairy root clones were ground under liquid nitrogen, and the powder was suspended in 1:1 phosphate buffer $w / v$. The recombinant protein was purified using low pressure chromatography system from GE Healthcare Life sciences (ÄKTA start, UNICORN start, and Frac30 fraction collector). Initially a HisTrap FF crude, 1 x $5 \mathrm{ml}$ (GE Life-sciences) column was equilibrated by loading $600 \mu \mathrm{L}$ of lysis buffer ( $25 \mathrm{mM} \mathrm{NaH} 2 \mathrm{PO} 4,150 \mathrm{mM} \mathrm{NaCl}, 10$ $\mathrm{mM}$ imidazole, $\mathrm{pH} 8.0$ ). Next, up to $800 \mu \mathrm{L}$ of concentrated root extract was loaded onto the column through the system pump. Then, the column was washed twice with $600 \mu \mathrm{L}$ of wash buffer ( $50 \mathrm{mM} \mathrm{NaH2PO} 4,300$ $\mathrm{mM} \mathrm{NaCl}, 20 \mathrm{mM}$ imidazole, $\mathrm{pH}$ 8.0). Finally, the protein was eluted twice using $300 \mu \mathrm{L}$ of elution buffer (50 mM NaH2PO4, $300 \mathrm{mM} \mathrm{NaCl}$, $500 \mathrm{mM}$ imidazole, $\mathrm{pH}$ 8.0) and collected $1 \mathrm{ml}$ fractions using Frac30 fraction collector at $1 \mathrm{ml} / \mathrm{min}$ flow rate and $80 \%$ step gradient method at $280 \mathrm{~nm}$. Then imidazole removed from pooled fractions using a 5 $\mathrm{ml} \mathrm{HiTrap}{ }^{\mathrm{sw}}$ Desalting column with the predefined Desalting template available in UNICORN start. Further purity of the protein analyzed the using SDS-PAGE, and ELISA immunodetection (BioEra Life Sciences) to confirm activity and specificity of the protein.

\section{SDS-PAGE}

The total proteins extracted from the transgenic and non-transgenic hairy roots were separated by $12.5 \%$ SDS-PAGE. ${ }^{710}$ Following electrophoresis, the gel was stained using Coomassie brilliant blue, TMN Buffer: Tris-MgCl2-NaCl buffer,

\section{Western blot analysis}

SDS-PAGE separated protein bands were transferred from the gel to a Hybond C Extra membrane (GE Healthcare). ${ }^{7,810}$ Purified bacteria LTB $(0.5 \mu \mathrm{g})$ were loaded as the positive control. Nonspecific antibody reactions were blocked by incubating the blot in $25 \mathrm{ml}$ of $3 \%(\mathrm{w} / \mathrm{v})$ bovine serum albumin (BSA) in TBST buffer (TBS + 0.05\% Tween-20) with gentle agitation overnight at room temperature. The blot was then incubated at room temperature for $2 \mathrm{~h}$ with gentle agitation in 10 $\mathrm{ml}$ of 1:2000 dilution of rabbit anti-LTB antiserum in TBST antibody dilution buffer containing $1.5 \%$ BSA and then washed three times with TBST buffer. Subsequently, the blot was incubated for $2 \mathrm{~h}$ at room temperature in a 1:5000 dilution of anti-rabbit IgG conjugated with alkaline phosphatase (Sigma-Aldrich) in TBST buffer and washed three times with TBST buffer and once with TMN buffer. After washing, the colour was developed with BCIP/NBT in TMN buffer.

\section{LTB-GM1 binding assay}

The ability of LTB protein to bind to gangliosides is indication of immunogenecity. ${ }^{7,8,10}$ The microwell plate was coated with $100 \mu \mathrm{l} /$ well of $3 \mu \mathrm{g} / \mathrm{ml} \mathrm{GM1}$ ganglioside (Sigma-Aldrich) in bicarbonate buffer, $\mathrm{pH} 9.6$ at $4^{\circ} \mathrm{C}$ overnight. After three washes with PBST, the wells were blocked with $1 \% \mathrm{BSA}$ in $0.01 \mathrm{M}$ PBS $(300 \mu \mathrm{l} /$ well $)$ at $37^{\circ} \mathrm{C}$ for $2 \mathrm{~h}$. The wells were washed three times with PBST and then incubated with the protein extract $(100 \mu \mathrm{l} /$ well $)$ from the LTB transgenic carrot hairy roots for $2 \mathrm{~h}$ at $37^{\circ} \mathrm{C}$. The wells were coated with $100 \mu \mathrm{l} /$ well of $3.0 \mu \mathrm{g} / \mathrm{ml}$ BSA as a control. For the primary and secondary antibody treatments, the wells were incubated with a 1:5000 dilution of rabbit anti-LTB antibody (Sigma-Aldrich) (100 $\mu \mathrm{l} /$ well) in $0.01 \mathrm{M}$ PBS containing $0.5 \%$ BSA for $2 \mathrm{~h}$ at $37^{\circ} \mathrm{C}$ and washed four times with PBST. Subsequently, the wells were incubated with a 1:10000 dilution of goat anti-rabbit IgG conjugated with horseradish peroxidase (Sigma-Aldrich) $(100 \mu \mathrm{l} /$ well) in $0.01 \mathrm{M}$ PBS containing $0.5 \% \mathrm{BSA}$ for $2 \mathrm{~h}$ at $37^{\circ} \mathrm{C}$ and washed four times with PBST. Finally, the plate was incubated with $100 \mu \mathrm{l} /$ well TMB substrates (Sigma-Aldrich) for $30 \mathrm{~min}$ at RT in the dark. After incubation, the reaction was measured at an absorbance of $620 \mathrm{~nm}$ in an automated ELISA system (BioEra).

\section{RESULTS AND DISCUSSION}

Confirmation of transformation of Agrobacterium in carrot explants is done by important morphological markers i.e. profusion of rapid growth, lateral branching and growth (Figure 1). Transgenic carrot hairy roots were successfully obtained. The integration of LTB gene in the carrot hairy roots is confirmed by polymerase chain reaction (PCR) (Figure 2). Western blot analysis of hairy roots carried out to confirm immunogenicity of the soluble proteins from the transgenic group against anti-LTB antiserum which revealed that specific signal from transgenic carrot hairy roots compared to no signal from untransformed roots. Results further confirm that transgenic carrot hairy roots are able to produce each oligomer of the LTB pentamer and show a similar banding pattern to the native bacterial derived LTB. Enzymelinked immunosorbent assay (ELISA) was carried out to detect the antigen presence in the total soluble proteins from transgenic carrot hairy roots. Results of the ELISA and Western blot (Figures 3 and 4) showed $10-15 \mu \mathrm{g}$ (0.75-1.2\%) approximate amount of recombinant 

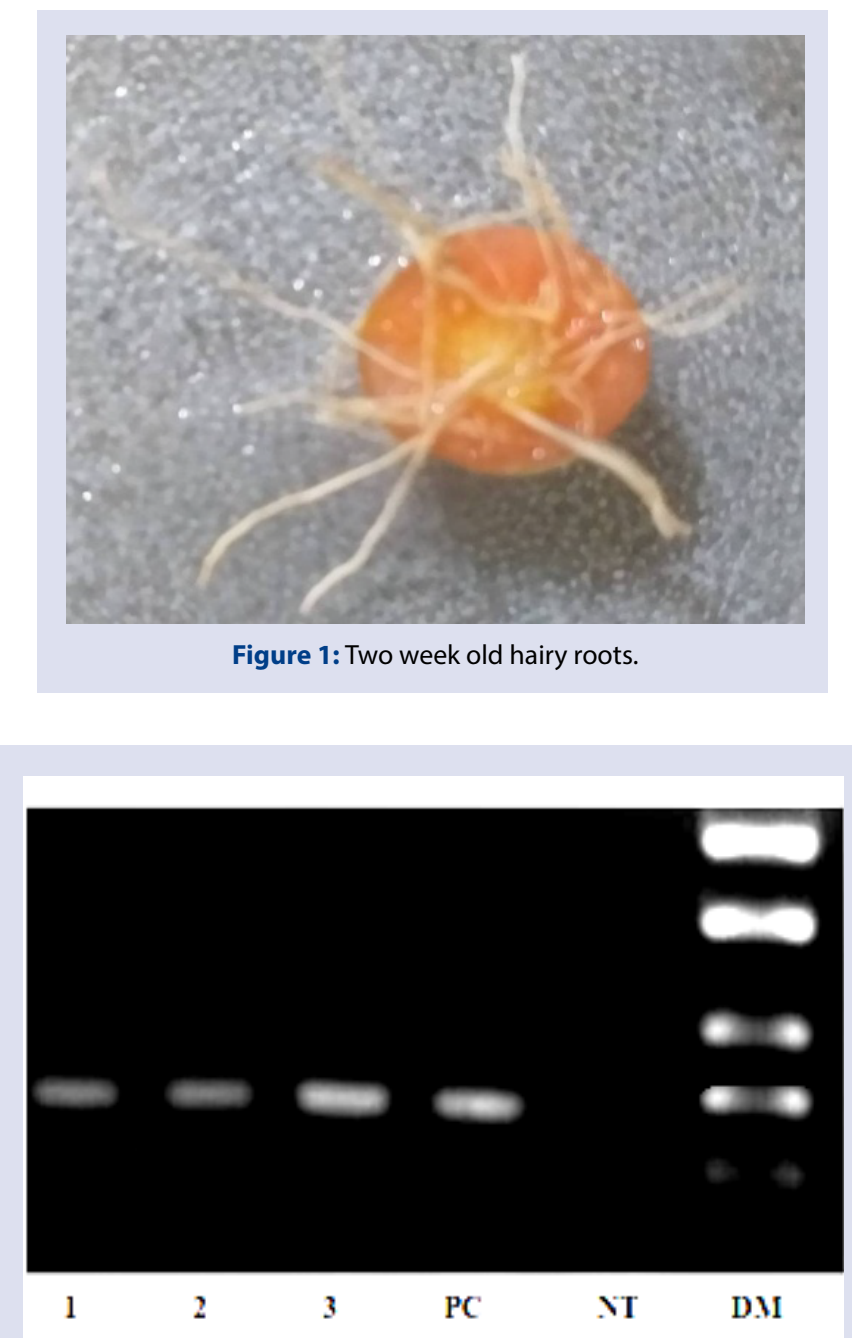

Figure 2: Genomic DNA PCR amplification to confirm the LTB gene in transgenic carrot roots DM - DNA size marker ( $\lambda$ DNA/EcoRI+HindIII), PC - pMYO51 vector, NT - non-transgenic carrot root, lanes 1-3 - LTB transgenic hairy roots.

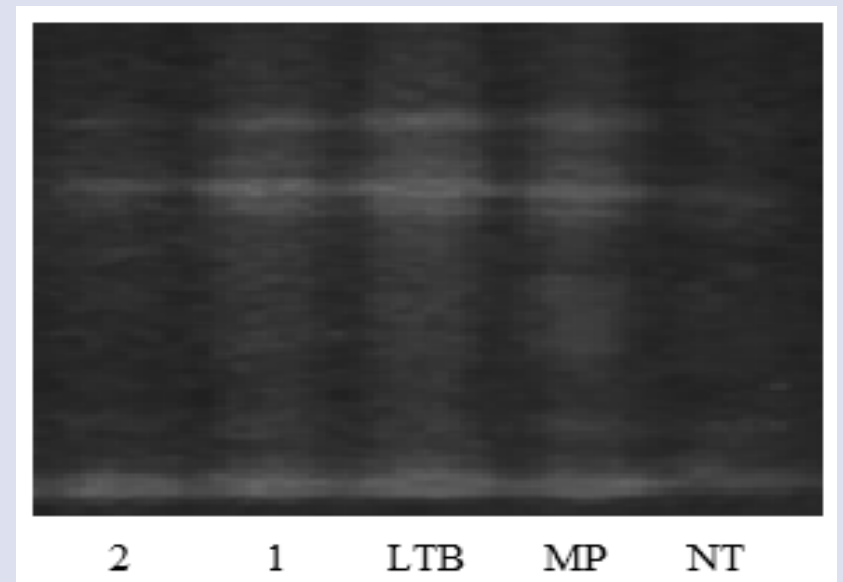

Figure 3: Western blot analysis showing immune activity of LTB protein expressed in transgenic carrot hairy roots where MP - protein weight marker (15-150 kDa); LTB -LTB protein; NT - non-transformed hairy roots; lanes 1-2: LTB transgenic hairy roots.

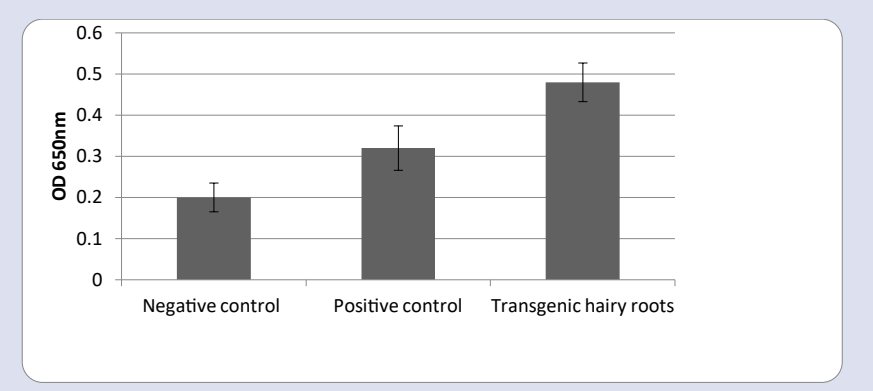

Figure 4: Protein expression analysis in transgenic carrot hairy roots by ELISA. Immune reactivity and the OD620 values of transgenic hairy roots significantly higher than negative control (proteins extracted from untransformed hairy roots) and positive control (wild carrot roots).

plant-synthesized LTB protein per gram of fresh blotted hairy roots. The result showed that the soluble proteins from the transgenic group had immune reactivity against rabbit anti-LTB antiserum and the OD620 values of the transgenic groups were significantly higher than those of the negative controls which implied that LTB protein was expressed and accumulated in transgenic carrot hairy roots. LTB protein produced in carrot hairy roots demonstrated a strong relative affinity to GM1ganglioside in the GM1-ELISA binding assays which also confirms LTB pentameric structure.

\section{CONCLUSION}

We conclude that nontoxic B subunit of Escherichia coli heat-labile enterotoxin (LTB) proteins can be effectively expressed in transgenic carrot hairy roots and useful as an antigen source for a possible vaccine against diarrhoea. Research can be extended to in-vivo immune activity determination and scale-up of transgenic hairy root in suitable bioreactors.

\section{ACKNOWLEDGEMENT}

Dr. Sharada L Deore is thankful to AICTE, New Delhi to support this work under RPS (8023/RID/RPS-44/2011-12) scheme.

\section{CONFLICTS OF INTEREST}

The authors declare no conflicts of interest

\section{ABBREVIATIONS}

LTB: Nontoxic B subunit of Escherichia coli heat-labile enterotoxin, PCR: Polymerase chain reaction, YEB: Yeast Extract Beef media, BSA:Bovine Serum Albumin, BCIP:5-bromo-4-chloro-3-indolylphosphate, NBT: Nitro Blue Tetrazolium, TBST: Tris-buffered saline, $0.1 \%$ Tween 20, ELISA: Enzyme-linked immunosorbent assay, $\mathrm{GM}_{1}$ : monosialotetrahexosylganglioside.

\section{REFERENCES}

1. Hefferon K. Plant-derived pharmaceuticals for the developing world. Biotechnol J. 2013;8(10):1193-202.

2. Franconi R, Demurtas OC, Massa S. Plant-derived vaccines and other therapeutics produced in contained systems. Expert Rev Vaccines. 2010;9(8):877-92.

3. Samadi A, Jafari M, Nejhad NM, Hossenian F. Podophyllotoxin and 6-methoxy podophyllotoxin Production in Hairy Root Cultures of Liunm mucronatum ssp. mucronatum. Phcog Mag. 2014;10:154-60

4. Kowalczyk T, Łucka M, Szemraj J, Sakowicz T. Hairy roots culture as a source of valuable biopharmaceuticals. Postepy Hig Med Dosw (Online). 2016;70:1-9.

5. Skarjinskaia M, Ruby K, Araujo A, Taylor K, Gopalasamy-Raju V, et al. Hairy roots as a vaccine production and delivery system. Adv Biochem Eng Biotechnol. 2013;134:115-34 
6. Florack DE, Matos Cl, Rouwendal GJ, Bosch D. Generation of LTB-based mucosal vaccines and production in plants. J Control Release. 2005;101(13):399-400.

7. Nguyen Hoang Loc, Dang Thanh Long, Tae-Geum Kim and Moon-Sik Yang. Expression of Escherichia coli Heat-labile Enterotoxin B Subunit in Transgenic Tomato (Solanum Iycopersicum L.) Fruit. Czech J Genet Plant Breed. 2014:2631.
8. Yugang Gao, Xueliang Zhao, Chao Sun, Pu Zang, He Yang, Ran Li, et al A transgenic ginseng vaccine for bovine viral diarrhea. Virology Journal 2015:12:73.

9. Ueki S, Magori S, Lacroix B, Citovsky V. Transient gene expression in epidermal cells of plant leaves by biolistic DNA delivery. Methods Mol Biol. 2013;940:17-26.

10. De Guzman G, Walmsley AM, Webster DE, Hamill JD. Hairy roots cultures from different Solanaceous species have varying capacities to produce E. coli B-subunit heat-labile toxin antigen. Biotechnol Lett. 2011;33(12):2495-502.

\section{GRAPHICAL ABSTRACT}

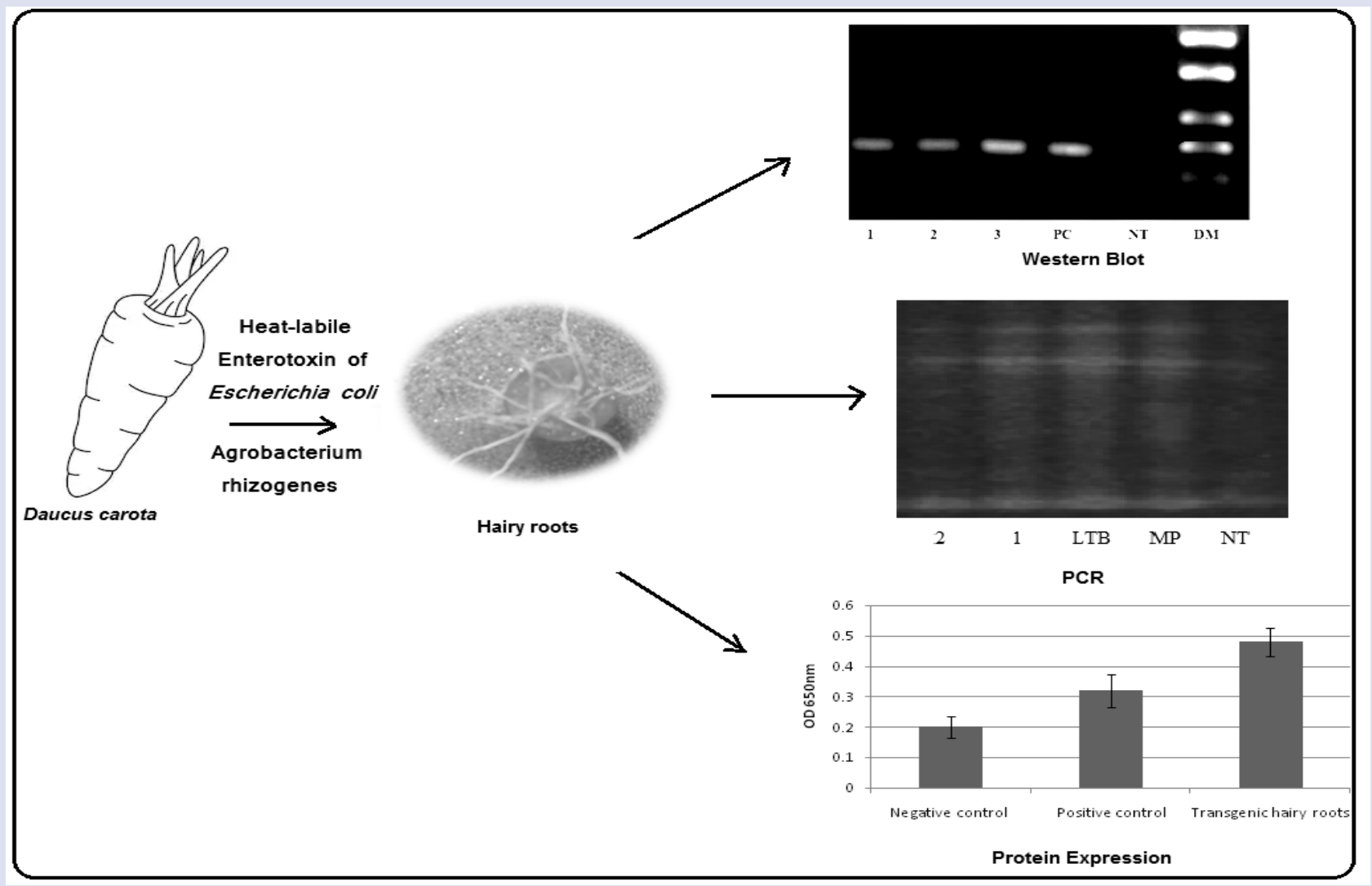

Cite this article: Deore SL, Khadabadi SS, Baviskar BA. Expression of Heat-labile Enterotoxin of Escherichia coli in Biolistic Transformed Hairy Roots of Daucus carota L. Pharmacogn J. 2020;12(6):1440-3. 